\title{
The clinical course of children undergoing mastoidectomy due to complicated mastoiditis
}

\author{
Oren Ziv ${ }^{1}$, Aviad Sapir ${ }^{1}$, Eugene Leibowitz ${ }^{1}$, Sofia Kordeluk ${ }^{1}$, Daniel KAPLAN ${ }^{2}$, and Sabri \\ El-Saied $^{3}$ \\ ${ }^{1}$ Soroka Medical Center \\ ${ }^{2}$ Soroka University Medical center \\ ${ }^{3}$ SoSoroka University Medical Center
}

February 7, 2021

\begin{abstract}
Objectives: To determine the immediate post-operative course and outcome of pediatric patients with complicated acute mastoiditis (CAM) undergoing simple mastoidectomy. Study Design: A retrospective chart review of children diagnosed with CAM who underwent a mastoidectomy during 2012-2019. Setting: Tertiary care university hospital. Participants: 33 patients were divided into two groups: 17 patients with subperiosteal abscess (SPA) alone- single complication group (SCG) and 16 patients with SPA and additional complications (sigmoid sinus vein thrombosis, perisinus fluid/abscess, epidural abscess)-multiple complications group (MCG). Main Outcome Measures: post-operative data were collected. Demographics, microbiology data, inflammatory parameters, hospitalization length, and POF pattern were recorded, compared, and analyzed. Results: Of 162 acute mastoiditis patients, 33(20.4\%) underwent surgery due to CAM; $17(51 \%)$ and 16(49\%) belonged to the SCG and MCG, respectively. 6/17(35.3\%) SCG patients experienced POF vs. $12 / 16(75 \%)$ in the MCG $(\mathrm{P}=0.012)$. At post-operative day 2 (POD2), 10/13(77\%) febrile patients belonged to MCG and 3/13(23\%) to SCG ( $\mathrm{P}=0.013)$. POF was recorded until POD6 in both groups. Seven patients, all from MCG with POF, underwent second imaging with no new findings; A total of 18 positive cultures were reported. Fusobacterium necrophorum counted for 8/18(44.5\%) of all positive cultures, $7 / 9(77.8 \%)$ in the MCG vs. $1 / 9(11.1 \%)$ in the SCG, $\mathrm{P}=0.004$. Streptococcus pneumoniae was reported only in SCG $(5 / 9,55.5 \%$, vs. $0 / 9, \mathrm{P}=0.008)$. Conclusion: Post-mastoidectomy fever due to CAM is not unusual and seems to be a benign condition for the first 5-6 days following surgery. MCG patients are more prone to develop POF. F. necrophorum is more likely to be associated with MCG, and S. pneumoniae is common in SCG patients. Keywords: Mastoiditis, post-operative fever, complications, microbiology
\end{abstract}

\section{Abstract}

Objectives: To determine the immediate post-operative course and outcome of pediatric patients with complicated acute mastoiditis (CAM) following surgical treatment.

Study Design: A retrospective chart review of children diagnosed with CAM who underwent mastoid surgery during 2012-2019.

Setting: Tertiary care university hospital.

Participants: the study includes 33 patients, divided into two groups: 17 patients with subperiosteal abscess (SPA) alone - single complication group (SCG) and 16 patients with SPA and additional intracranial or intratemporal complications -multiple complications group (MCG).

Main Outcome Measures: post-operative fever course and pattern (POF), microbiology data, inflammatory parameters, hospitalization length, were recorded, compared, and analyzed. 
Results : 33 patients belong to the SCG 17(51\%) and 16(49\%) belonged to the MCG, respectively. 6/17(35.3\%) SCG patients experienced POF vs . 12/16(75\%) in the MCG ( $\mathrm{P}=0.012)$. At post-operative day 2 (POD2), 10/13(77\%) febrile patients belonged to MCG and 3/13(23\%) to SCG (P=0.013). POF was recorded until POD6 in both groups. Seven patients, all from MCG with POF, underwent second imaging with no new findings; A total of 18 positive cultures were reported.Fusobacterium necrophorum counted for $8 / 18(44.5 \%)$ of all positive cultures, $7 / 9(77.8 \%)$ in the MCG vs. $1 / 9(11.1 \%)$ in the SCG, $\mathrm{P}=0.004$. Streptococcus pneumoniae was reported only in SCG $(5 / 9,55.5 \%$, vs. $0 / 9, \mathrm{P}=0.008)$.

Conclusion: Post-mastoidectomy fever due to CAM is not unusual and seems to be a benign condition for the first 5-6 days, following surgery. MCG patients are more prone to develop POF. F. necrophorum is more likely to be associated with MCG, and S. pneumoniae is common in SCG patients.

Keywords: complications, mastoiditis, microbiology, post-operative fever.

\section{Key points:}

1. Post-operative fever after cortical mastoidectomy due to complicated acute mastoiditis may be a benign sign in duration of 5-6 days post operatively.

2. In cases of multiple acute mastoiditis complications, higher and prolonged fever is more likely, compared to single complication cases.

3. S. pneumoniae is the common pathogen in patients with single acute mastoiditis complication, while $F$. necrophorum is associated with multiple complications.

\section{Introduction}

Acute mastoiditis (AM) is a complication of acute otitis media and is common in the pediatric population (1-3). Management is usually conservative and includes performing a wide myringotomy, middle ear fluid (MEF) cultures, and parenteral administring antibiotics. Patients who develop complications or do not respond to treatment will most often undergo diagnostic imaging and a cortical mastoidectomy $(1,2,4)$.

The most common complications seen in children with AM are a sub-periosteal abscess (SPA), sigmoid sinus thrombosis (SST), peri-sinus fluid/abscess, epidural/subdural abscess, and acute meningitis. These complications are diagnosed clinically and radiologically ${ }^{(5)}$. Surgery with ventilation tube insertion, has a vital role in treating complicated mastoiditis, along with antibiotics ${ }^{(6)}$, antipyretics, and anticoagulation, in cases of $\operatorname{SST}^{(7)}$.

The management of a febrile child with CAM whether with or without clinical improvement becomes challenging. In such cases, repeated imaging and revision surgery and would be considered. On the other hand, imaging in such circumstances possesses several limitations; At a young age post-contrast head CT usually requires general anesthesia and is associated with substantial ionizing radiation. Head MRI is superior for evaluating soft tissue details such as of peri-sinus abscess and presence of SST but is less available, is costly, and requires an extended general anesthesia period.

The main aim of the present study was to characterize the immediate follow-up of children with CAM following surgery, regarding the post-operative fever (POF), the inflammatory parameters and to define the microbiology.

2. Materials and methodsIn this cohort retrospective study we followed STROBE methodology Guidelines.

\subsection{Ethical considerations:}

The study was approved by [Blinded for review] Medical Center's Helsinki committee.

\subsection{Participants}


In this study we reviewed patients underwent a cortical mastoidectomy due to complicated mastoiditis at [Blinded for review] between 2012- 2019.

Data collected : demographics, microbiology, antibiotic treatment, hospitalization length.

Inflammatory parameters : white blood cell (WBC) count and C-reactive protein (CRP) at admission and during the hospitalization

\subsection{Fever}

Post-operative body temperature was assessed every eight hours via the rectal or axillary route and was defined as any body temperature of $[?] 38.0^{\circ} \mathrm{C}$.

\subsection{Treatment groups and complications}

The single complication group (SCG) was defined as all children diagnosed with complicated mastoiditis and SPA alone. Multi complications group (MCG) included patients with additional intratemporal or intracranial complication (peri-sinus fluid/abscess, epidural abscess, SST, and acute meningitis).

Complications were defined as either a SPA or any clinical finding on physical examination and/or by imaging (post-contrast head CT or head MRI) pre/intra-operatively.

\subsection{Department AM protocol}

Generally, children presenting with AM are hospitalized and treated with intravenous antibiotics. A wide myringotomy is performed at admission (under local anesthesia), and culture is obtained from the middle ear. When CAM is suspected clinically (persistent fever and lack of improvement/deterioration in clinical findings), the patient is evaluated by a head and temporal bone high-resolution computerized tomography with contrast material. Once imaging reveals the presence of a complication, surgery is planned, which includes a cortical mastoidectomy and insertion of an ipsilateral ventilation tube (VT). In cases of peri-sinus abscesses, drainage and bony decompression of the sinus is performed. Anticoagulants are administered for three months in cases of SST cases and the patient is followed with repeated head MRIs.

\subsection{Statistical analysis}

Patient characteristics were presented as mean \pm SD for continuous variables with normal distribution and categorical variables presented as a percentage. Continuous variables were examined using the student's ttest. Categorical variables were compared using the chi-square test. Data were analyzed using the Statistical Package for Social Sciences (IBM SPSS Chicago, USA, version 22). In all analyses, the alpha level was set to 0.05 .

\section{Results}

\subsection{Demographics and inflammatory parameters at presentation}

We identified 33 patients with CAM who underwent a cortical mastoidectomy and ipsilateral ventilation tube (Table 1).

There were 15 (45\%) males and $18(55 \%)$ females. The mean age was $2.63 \pm 3.05$ years (range 6 months to 13 years). Seventeen (51\%) were included in the SCG and sixteen (49\%) in the MCG. Length of hospitalization was significantly higher in the MCG, $12.4 \pm 6.6$ vs $.7 .5 \pm 2.5$ days in the SCG $(\mathrm{P}=0.008)$. WBC counts and CRP values at admission were 19,782 cells $/ \mathrm{mm}^{3}$ and $124.25 \mathrm{mg} / \mathrm{Dl}$ in the SCG compared with 16,524 cells $/ \mathrm{mm}^{3}$ and $129.19 \mathrm{mg} / \mathrm{Dl}$ in the $\mathrm{MCG}$, respectively $(\mathrm{P}=0.229$ and $\mathrm{P}=0.89$, respectively). Anticoagulants were administered only in patients with SST.

\subsection{Timing of surgery and laboratory findings}

Table 2 presents the patients' clinical characteristics and laboratory findings on the day of surgery. Surgery was performed on days 1-5 of hospitalization (three patients on day 1, eighteen on day 2, eight on day 3 , three on day 4, and one on day 5), with no difference between the two groups in respect to mean timing 
for surgery $(2.47 \pm 0.8$ days after admission in the SCG vs . $2.37 \pm 0.9$ days in the MCG, $\mathrm{P}=0.766)$. No differences were found between the study groups regarding mean body temperature measurements, CRP levels, and WBC counts recorded on the day of surgery.

\subsection{Imaging}

All 33 patients underwent a post-contrast head CT and temporal bone HRCT prior to surgery. Imaging demonstrated $17(51 \%)$ children had SPA alone, 6 (18\%) had SPA with SST, 4 (12\%) had SPA with perisinus collection, $4(12 \%)$ had SPA , SST and peri-sinus collection, $1(3 \%)$ child had SPA SSTSST with epidural abscess and $1(3 \%)$ child had SPA + with epidural abscess.

\subsection{Microbiology}

MEF cultures were obtained from all 33 patients (Table 3) and 16 (48.5\%) were positive. Fusobacterium necrophorum was the most commonly isolated pathogen ( 6 patients, $18.2 \%$ of all patients), being isolated more frequently in the MCG $(5 / 16,31.25 \%)$ vs . SCG $(1 / 17,5.9 \%, \mathrm{P}=0.058$. F . necrophorum counted for $6 / 16(37.5 \%)$ of positive MEF cultures, 5/7 (71.5\%) in the MCG vs. $1 / 9(11.1 \%)$ in the SCG, $\mathrm{P}=0.013$.

Streptococcus pneumoniae, either as a single pathogen or in mixed cultures was isolated in 5/9 (55.5\%) patients from the SCG and in 0/7 patients from the MCG $(\mathrm{P}=0.017)$. Four out of five (80\%) S. pneumoniae isolates were susceptible to penicillin, and all five were susceptible to ceftriaxone.

Two patients had positive mastoid cultures (both of them with the growth of $F$. necrophorum) reported from the operating theater, while the MEF cultures of these two patients were negative. Two additional patients had a similar pathogen (Streptococcus pyogenes ) isolated from the mastoid and MEF cultures; 14 additional mastoid cultures were reported sterile at the surgery.

When including the mastoid with the MEF cultures, a total of $18(54.5 \%)$ cultures were positive. F. necrophorum counted for 8/18 (44.5\%) of total positive cultures, $7 / 9(77.8 \%)$ in the MCG vs . 1/9 (11.1\%) in the SCG, $\mathrm{P}=0.004$. Including mastoid positive cultures, Streptococcus pneumoniae was reported more frequently in the SCG, $5 / 9(55.5 \%)$ vs. $0 / 9$ in the MCG, $\mathrm{P}=0.008$.

\subsection{Post-operative fever}

Both SCG and MCG exhibited POF, the magnitude and duration differed between the two groups (Figure 1) : 6/17(35.3\%) SCG patients experienced fever at some point post-operatively vs . $12 / 16(75 \%)$ in the MCG $(\mathrm{P}=0.012)$.

POF was higher and of longer duration in the MCG. The mean fever at post-operative day (POD) 1 was $37.8 \pm 0.9$ in the $\mathrm{SCG}$ and $37.7 \pm 1$ in the MCG $(\mathrm{P}=0.71)$. On POD2, the mean temperature was lower in the SCG vs . the MCG (37.29 vs . 38.17, $\mathrm{P}=0.035)$. On POD6, the mean temperature was lower in the SCGvs . the MCG (37.44 vs . 37.58 , respectively, $\mathrm{P}=0.32$ ).

Figure 2 presents only febrile children $\left([?] 38^{0} \mathrm{C}\right)$ in the two groups. At POD2, 10/13 (77\%) febrile patients belonged to MCG and 3/13 (23\%) belonged to the SCG $(\mathrm{P}=0.013)$. On POD6, only single child from the SCG had fever. This child had undergone another CT scan, and no new complications were found.

\subsection{Post-operative inflammatory parameters}

Of the 33 patients, 18 (55\%) (7 from the SCG and 11 from the MCG) had blood tests performed between the operation day and their discharge day. Twelve of these tests $(66 \%)$ were performed due to persistent high fever.

Four $(57.1 \%)$ out of the seven patients from the SCG had leukocytosis $\left(>15,000\right.$ cells $\left./ \mathrm{mm}^{3}\right)$ compared with $10(90.9 \%)$ of the 11 patients from the MCG $(\mathrm{P}=0.09)$. Of the 18 patients that had blood tests postoperatively, all had elevated CRP levels. The mean CRP levels in the SCG were $62.4+-46.3(\mathrm{mg} / \mathrm{dl})$ and $77.57+-52.1(\mathrm{mg} / \mathrm{dl})$ in the MCG.

\subsection{Post-operative imaging}


Seven of the 33 patients required a second imaging test performed on average on POD5 (Table 4), and all belonged to the MCG. The main indication for performing the second imaging was continuous fever. No new complications were found on any of the repeated imaging.

\subsection{Repeated surgery}

Five patients (15\%) had a second surgical procedure, performed after an average time of 4 days following the first surgery. Four of them were from MCG and additional single patient was from SCG. One patient had an examination under anaesthesia, and two additional ones had reinsertion of a VT. Two (6\%) patients underwent a second surgical procedure due to prolonged POF. Table 4 presents the indications and imaging findings before the revision surgery and the intra-operative findings.

\section{Discussion}

In the present study, we characterized the clinical course and the microbiologic findings of CAM in children. The study's retrospective nature raises several possible limitations: 1 . some clinical and laboratory data from the patient charts were incomplete or missing. 2. Several otolaryngologists and pediatricians treated the patients. Therefore, decisions related to the need for repeated imaging and the need for revision surgery might not have been uniform.

Most AM cases are managed conservatively, with myringotomy, intravenous antibiotics, and a careful followup, until resolution of the disease. Some patients may develop complications, either extra or intra-cranial; these cases are defined as CAM and treated surgically, while continuing systemic antibiotic treatment. The surgical management may differ between various medical centers and include myringotomy, placement of VT, and incision plus drainage of SPA, with or without cortical mastoidectomy. Patients presenting intracranial complications are most likely to undergo a mastoidectomy ${ }^{(8)}$. In a series of 570 children published recently from Israel, reported a significant increase in AM cases that had an indication for surgical intervention during the years $2008-2017$ (11\% vs. $19 \%$ between the first and the last five years of the study respectively, $\mathrm{P}=$ 0.008 ) and described higher fever, leukocytes counts and CRP values in CAM compared to simple $\mathrm{AM}^{(9)}$. A study from the UK ${ }^{(10)}$, described 30 patients (aged 2 months to 15 years) with intracranial complications of AM. The most frequent complication was SST (73\%), followed by a cerebral abscess (40\%) and SPA (33\%). Three (10\%) patients had long-term sequelae (one developed secondary intracranial hypertension, the second a CSF leak that required placement of a ventriculo-peritoneal shunt, and the third with diplopia and residual mild visual obscuration); only one (3\%) patient required additional surgical treatment. In a recent study from the United States, addressing the safety and post-operative adverse events encountered during the management of $\mathrm{AM}{ }^{(11)}, 113$ patients with AM requiring surgical treatment were analyzed. Four $(3.1 \%)$ patients required readmission and $9(6.9 \%)$ required unplanned subsequent operative procedures.

\section{POF and infection}

The present study addresses the detailed post-operative course of CAM, following surgery. POF is a known entity in surgery in general and in ear surgery in particular. El-Saied et al . ${ }^{(12)}$ reported an overall POF incidence of $19.2 \%$ after cochlear implant surgery and showed that POF was unrelated to infectious or local complications and did not seem to have any long-term significance. Nevertheless, in contrast to the AM cochlear implants is an elective and "clean" procedure. In the setting of CAM; an acute infectious disease requiring surgery for purulent drainage and reduction of bacterial load, POF may be a sign of complications, requiring further investigation and treatment. To the best our knowledge our present study is the first to characterize the POF course of CAM. We found that POF is different in magnitude and behavioral patterns in SCG and in MCG. We found that in any given POD in the MCG, the fever tended to be more common and higher. However, around POD6, no differences were recorded in the values of fever measured between the two study groups, and the fever normalized in the majority of the patients. This is an important finding for clinicians, suggesting that in a patient with CAM (diagnosed either by preoperative imaging or intraoperative findings), POF should be expected and does not necessarily mean lack of control of the infection that would require repeated imaging and possibly revision surgery. 


\section{Microbiology}

Significant differences were seen in this study between the pathogens of the SCG and that of MCG. F. necrophorum was more commonly associated with MCG (representing $71 \%$ of the positive cultures reported in these patients) while $S$. pneumoniae was isolated only in patients with SCG. The high rates of $F$. necrophorum in our study are similar to those reported by Stern-Shavit et al.$^{(9)}$ and describing a significant increase in the role of $F$. necrophorum in the pathophysiology of CAM. In this retrospective study conducted between the years 2008-2017, 570 cases of AM were investigated. A significant rise in the role of F. necrophorum in the pathophysiology of CAM was recorded ( $F$. necrophorum isolated in half of the cases). However, in their study, PCR was used for detecting additional pathogens in initially negative MEF cultures, while PCR was not routinely used in our institution during the study period.

\section{Repeated-imaging and revision-surgery}

Twenty-one percent (7/33) of the study patients underwent post-surgery imaging; of them, only two patients required a second surgical procedure. All patients underwent post-surgical imaging belonged to the MCG. The most common findings in the repeated imaging showed only the previously known complications and post-surgical changes. Therefore, our study confirmed that a low percentage of patients with CAM might require repeated imaging and revision surgery. However, since fever usually continues in the first few PODs, waiting and close clinical follow-up for at least 4 to 5 days after surgery seems to be sufficient in most cases before considering additional diagnostic and therapeutic steps.

\section{Conclusions}

Following a cortical mastoidectomy for CAM, fever can be expected for up to 6 days. Fever is more common, is higher, and persists for a longer duration in MCG compared with SCG. At POD 6, fever is expected to normalize in both groups, and if still present, further evaluation should be considered. F. necrophorum is most commonly associated with multiple AM complications, while $S$. pneumoniae and nontypeable $H$. influenzae are predominantly isolated in the group of patients with single complication-AM.

\section{Data Availability Statement}

The datasets generated during and/or analyzed during the current study are available from the corresponding author on reasonable request.

\section{References}

1. Loh R, Phua M, Shaw CL. Management of paediatric acute mastoiditis: systematic review. J Laryngol Otol . 2018; 132:96-104. doi:10.1017/S0022215117001840

2. Ren Y, Sethi RKV, Stankovic KM. Acute Otitis Media and Associated Complications in United States Emergency Departments. Otol Neurotol . 2018; 39:1005-1011. doi:10.1097/MAO.0000000000001929

3. Mansour T, Yehudai N, Tobia A, et al. Acute mastoiditis: 20 years of experience with a uniform management protocol. Int J Pediatr Otorhinolaryngol . 2019; 125:187-191. doi:10.1016/j.ijporl.2019.07.014

4. Alkhateeb A, Morin F, Aziz H, Manogaran M, Guertin W, Duval M. Outpatient management of pediatric acute mastoiditis. Int $J$ Pediatr Otorhinolaryngol . 2017; 102:98-102. doi:10.1016/j.ijporl.2017.09.008

5. Mather MW, Yates PD, Powell J, Zammit-Maempel I. Radiology of acute mastoiditis and its complications: a pictorial review and interpretation. J Laryngol Otol . 2019; 1-6. doi:10.1017/S0022215119001609

6. Mierzwiński J, Tyra J, Haber K, et al. Therapeutic approach to pediatric acute mastoiditis - an update. Braz J Otorhinolaryngol . 2019; 85:724-732. doi:10.1016/j.bjorl.2018.06.002

7. Mather M, Musgrave K, Dawe N. Is anticoagulation beneficial in acute mastoiditis complicated by sigmoid sinus thrombosis? Laryngoscope . 2018; 128:2435-2436. doi:10.1002/lary.27151 
8. Ghadersohi S, Young NM, Smith-Bronstein V, Hoff S, Billings KR. Management of acute complicated mastoiditis at an urban, tertiary care pediatric hospital. Laryngoscope. 2017; 127:2321-2327. doi: 10.1002/lary.26365.

9. Stern Shavit S, Raveh E, Levi L, Sokolov M, Ulanovski D. Surgical intervention for acute mastoiditis: 10 years experience in a tertiary children hospital. Eur Arch Otorhinolaryngol. 2019; 276:3051-3056. doi:10.1007/s00405-019-05606-2

10. Krishnan M, Walijee H, Jeurasa A, et al. Clinical outcomes of intracranial complications secondary to acute mastoiditis: The Alder Hey experience. Int J Pediatr Otorhinolaryngol. 2020; 128: 109- 115. doi:10.1016/j.ijporl.2019.109675.

11. Crowson MG, Cheng J. Safety and post-operative adverse events in management of acute mastoiditis in children - 30 Day NSQIP outcomes. Int J Pediatr Otorhinolaryngol. 2018; 108:132-136. doi:10.1016/j.ijporl.2018.02.043

12. El-Saied S, Joshua BZ, Abu Tailakh M, et al. Early post-operative fever in paediatric patients undergoing cochlear implant surgery. Clin Otolaryngol . 2018; 43:385-388. doi:10.1111/coa.13009

Figure/Table list:

Figure 1.

Fever behavior patterns in complicated acute mastoiditis; comparison between SCG and MCG

Figure 2.

Post-operative fever [?] $38^{\circ} \mathrm{C}$; comparison between SCG and MCG patients

Table 1. 33 children with complicated acute mastoiditis; demographic, clinical, laboratory and management parameters:

\begin{tabular}{|c|c|c|c|c|}
\hline & Total $n=33$ & $\mathbf{S C G} \mathbf{n}=17$ & MCG $n=16$ & P-Value \\
\hline $\begin{array}{l}\text { Male n (\%) Female } \\
\text { n (\%) }\end{array}$ & $\begin{array}{l}15(45.45) 18 \\
(54.54)\end{array}$ & $9(53) 8(47)$ & $6(37.5) 10(62.5)$ & 0.373 \\
\hline $\begin{array}{l}\text { Jewish n (\%) } \\
\text { Bedouin n (\%) }\end{array}$ & $23(69.7) 10(30.3)$ & $\begin{array}{l}11(64.7 \%) 6 \\
(35.3 \%)\end{array}$ & $12(75) 4(25)$ & 0.52 \\
\hline $\begin{array}{l}\text { Age at } \\
\text { hospitalization } \\
(\text { mean } \pm \mathrm{SD})\end{array}$ & $2.63( \pm 3.05)$ & $2.25( \pm 2.83)$ & $3.04( \pm 3.31)$ & 0.469 \\
\hline $\begin{array}{l}\text { Hospitalization } \\
\text { length (days, mean } \\
\pm \text { SD) }\end{array}$ & $9.9( \pm 5.46)$ & $7.52( \pm 2.57)$ & $12.43( \pm 6.6)$ & 0.008 \\
\hline $\begin{array}{l}\text { Fever at } \\
\text { admission }\left(\mathrm{C}^{\circ}\right. \\
\text { mean } \pm \mathrm{SD})\end{array}$ & $38.30( \pm 1.22)$ & $38.12( \pm 1.1)$ & $38.5( \pm 1.35)$ & 0.386 \\
\hline $\begin{array}{l}\text { WBC at } \\
\text { admission } \\
(\text { cells } / \text { mm } 3, \text { mean } \\
\pm \text { SD) }\end{array}$ & $18,203( \pm 7,677)$ & $19,782( \pm 7,101)$ & $16,524( \pm 8,130)$ & 0.229 \\
\hline $\begin{array}{l}\text { CRP at admission } \\
(\mathrm{mg} / \mathrm{dl}, \text { mean } \pm \\
\mathrm{SD})\end{array}$ & $126.72( \pm 95.15)$ & $124.25( \pm 102.9)$ & $129.19( \pm 93.17)$ & 0.891 \\
\hline $\begin{array}{l}\text { Anticoagulation } \\
\text { therapy } \mathrm{n}(\%)\end{array}$ & $6(18.2 \%)$ & 0 & $6 / 16(37.5)$ & 0.007 \\
\hline
\end{tabular}


CRP - C-reactive protein, WBC- white blood count, SCG - single complication group, MCG - multiple complications group

Table 2. Clinical characteristics and laboratory findings at operation day

\begin{tabular}{|c|c|c|c|c|}
\hline & Total $\mathbf{n}=33$ & SCG $n=17$ & MCG $n=16$ & P-Value \\
\hline $\begin{array}{l}\text { Day of } \\
\text { hospitalization } \\
\text { (days, mean } \pm \mathrm{SD})\end{array}$ & $2.42( \pm 0.9)$ & $2.47( \pm 0.8)$ & $2.37( \pm 0.9)$ & 0.766 \\
\hline $\begin{array}{l}\text { Laboratory } \\
\text { findings }\end{array}$ & $\begin{array}{l}\text { Laboratory } \\
\text { findings }\end{array}$ & $\begin{array}{l}\text { Laboratory } \\
\text { findings }\end{array}$ & $\begin{array}{l}\text { Laboratory } \\
\text { findings }\end{array}$ & $\begin{array}{l}\text { Laboratory } \\
\text { findings }\end{array}$ \\
\hline $\begin{array}{l}\text { Fever }\left(\mathrm{C}^{\circ}, \text { mean }\right. \\
\pm \mathrm{SD})\end{array}$ & $37.96( \pm 1.15)$ & $37.93( \pm 1.05)$ & $37.98( \pm 1.27)$ & 0.899 \\
\hline $\begin{array}{l}\text { WBC }\left(\text { cells } / \mathrm{mm}^{3},\right. \\
\text { mean } \pm \mathrm{SD})\end{array}$ & $16,583( \pm 6,807)$ & $14,562( \pm 6,613)$ & $18,154( \pm 6,908)$ & 0.311 \\
\hline $\begin{array}{l}\mathrm{CRP}(\mathrm{mg} / \mathrm{dl}, \\
\text { mean } \pm \mathrm{SD})\end{array}$ & $104.0( \pm 93.2)$ & $95.15( \pm 35.9)$ & $114.12( \pm 96.2)$ & 0.639 \\
\hline
\end{tabular}

CRP - C-reactive protein, WBC- white blood count, SCG - single complication group, MCG - multiple complications group

Table 3. Microbiology: 33 children with complicated acute mastoiditis

\begin{tabular}{lllll}
\hline Pathogen & Total $\mathbf{n}=\mathbf{3 3}$ & SCG $\mathbf{~}=\mathbf{1 7}$ & MCG n $=\mathbf{1 6}$ & P value \\
No growth (\%) & $17(51.5)^{*}$ & $8(47.1)$ & $9(56.25)$ & 0.59 \\
$\begin{array}{l}\text { Fusobacterium } \\
\text { necrophorum (\%) }\end{array}$ & $6(18.2)$ & $1(5.9)$ & $5(31.25)$ & 0.058 \\
$\begin{array}{l}\text { Streptococcus } \\
\text { pneumoniae (\%) }\end{array}$ & $4(12.1)$ & $4(23.5)$ & $0(0)$ & 0.03 \\
$\begin{array}{l}\text { Streptococcus } \\
\text { pyogenes (\%) }\end{array}$ & $3(9.1)$ & $1(5.9)$ & $2(12.5)$ & 0.5 \\
$\begin{array}{l}\text { Nontypeable H. } \\
\begin{array}{l}\text { Influenzae (\%) } \\
\text { S. pneumoniae+ } \\
\text { non-typeable H. }\end{array}\end{array}$ & $2(6.1)$ & $2(11.7)$ & $0(0)$ & 0.15 \\
influenzae(\%) & $1(3)$ & $1(5.9)$ & $0(0)$ & 0.32 \\
\hline
\end{tabular}

SCG - single complication group, MCG - multiple complications group

* in parentheses, $\%$ of all patients

Table 4. patients with second imaging and surgery

Patients with second imaging 


\begin{tabular}{|c|c|c|c|c|c|c|c|c|c|c|}
\hline & $\begin{array}{l}\text { Time } \\
\text { span } \\
\text { from } \\
\text { first } \\
\text { surgery } \\
\text { to } \\
\text { sec- } \\
\text { ond } \\
\text { imag- } \\
\text { ing } \\
\text { (days) }\end{array}$ & $\begin{array}{l}\text { Time } \\
\text { span } \\
\text { from } \\
\text { first } \\
\text { surgery } \\
\text { to } \\
\text { sec- } \\
\text { ond } \\
\text { imag- } \\
\text { ing } \\
\text { (days) }\end{array}$ & $\begin{array}{l}\text { SCG/MC } \\
\text { (type) } \\
\text { ac- } \\
\text { cod- } \\
\text { ing } \\
\text { to } \\
\text { 2nd } \\
\text { imag- } \\
\text { ing }\end{array}$ & $\begin{array}{l}\text { GCG / MC } \\
\text { (type) } \\
\text { ac- } \\
\text { cod- } \\
\text { ing } \\
\text { to } \\
\text { 2nd } \\
\text { imag- } \\
\text { ing }\end{array}$ & $\begin{array}{l}\text { Imaging } \\
\text { modal- } \\
\text { ity }\end{array}$ & $\begin{array}{l}\text { Imaging } \\
\text { modal- } \\
\text { ity }\end{array}$ & $\begin{array}{l}\text { Indication } \\
\text { for } \\
\text { sec- } \\
\text { ond } \\
\text { imag- } \\
\text { ing }\end{array}$ & $\begin{array}{l}\text { nIndicatio } \\
\text { for } \\
\text { sec- } \\
\text { ond } \\
\text { imag- } \\
\text { ing }\end{array}$ & $\begin{array}{l}\text { nSecond } \\
\text { imag- } \\
\text { ing } \\
\text { find- } \\
\text { ings }\end{array}$ & $\begin{array}{l}\text { Second } \\
\text { imag- } \\
\text { ing } \\
\text { find- } \\
\text { ings }\end{array}$ \\
\hline 1 & 10 & 10 & $\begin{array}{l}\text { MCG } \\
(\mathrm{SST})\end{array}$ & $\begin{array}{l}\text { MCG } \\
\text { (SST) }\end{array}$ & MRI & MRI & Fever & Fever & $\begin{array}{l}\text { Post- } \\
\text { surgi- } \\
\text { cal } \\
\text { changes }\end{array}$ & $\begin{array}{l}\text { Post- } \\
\text { surgi- } \\
\text { cal } \\
\text { changes }\end{array}$ \\
\hline 2 & 5 & 5 & $\begin{array}{l}\mathrm{MCG} \\
(\mathrm{SST})\end{array}$ & $\begin{array}{l}\text { MCG } \\
\text { (SST) }\end{array}$ & MRI & MRI & Fever & Fever & $\begin{array}{l}\text { Post- } \\
\text { surgi- } \\
\text { cal } \\
\text { changes }\end{array}$ & $\begin{array}{l}\text { Post- } \\
\text { surgi- } \\
\text { cal } \\
\text { changes }\end{array}$ \\
\hline 3 & 1 & 1 & $\begin{array}{l}\text { MCG } \\
(\mathrm{SST})\end{array}$ & $\begin{array}{l}\text { MCG } \\
(\mathrm{SST})\end{array}$ & $\mathrm{CT}$ & $\mathrm{CT}$ & Fever & Fever & $\begin{array}{l}\text { Post- } \\
\text { surgi- } \\
\text { cal } \\
\text { changes }\end{array}$ & $\begin{array}{l}\text { Post- } \\
\text { surgi- } \\
\text { cal } \\
\text { changes }\end{array}$ \\
\hline 4 & 5 & 5 & $\begin{array}{l}\text { MCG } \\
(\mathrm{SST})\end{array}$ & $\begin{array}{l}\text { MCG } \\
(\mathrm{SST})\end{array}$ & $\mathrm{CT}$ & $\mathrm{CT}$ & $\begin{array}{l}\text { Fever } \\
+ \\
\text { Suspi- } \\
\text { cion } \\
\text { for } \\
\text { SST }\end{array}$ & $\begin{array}{l}\text { Fever } \\
+ \\
\text { Suspi- } \\
\text { cion } \\
\text { for } \\
\text { SST }\end{array}$ & $\begin{array}{l}\text { Post - } \\
\text { surgi- } \\
\text { cal } \\
\text { changes }\end{array}$ & $\begin{array}{l}\text { Post - } \\
\text { surgi- } \\
\text { cal } \\
\text { changes }\end{array}$ \\
\hline 5 & 2 & 2 & $\begin{array}{l}\text { MCG } \\
\text { (Epidu- } \\
\text { ral } \\
\text { abscess }\end{array}$ & $\begin{array}{l}\text { MCG } \\
\text { (Epidu- } \\
\text { ral } \\
\text { abscess }\end{array}$ & $\mathrm{CT}$ & $\mathrm{CT}$ & Fever & Fever & $\begin{array}{l}\text { Epidural } \\
\text { ab- } \\
\text { scess } \\
\text { in } \\
\text { regression }\end{array}$ & $\begin{array}{l}\text { Epidural } \\
\text { ab- } \\
\text { scess } \\
\text { in } \\
\text { regression }\end{array}$ \\
\hline 6 & 2 & 2 & $\begin{array}{l}\text { MCG } \\
(\mathrm{SPA}, \\
\mathrm{SST})\end{array}$ & $\begin{array}{l}\text { MCG } \\
(\mathrm{SPA}, \\
\mathrm{SST})\end{array}$ & MRI & MRI & Fever & Fever & $\begin{array}{l}\text { post- } \\
\text { surgi- } \\
\text { cal } \\
\text { changes }\end{array}$ & $\begin{array}{l}\text { post- } \\
\text { surgi- } \\
\text { cal } \\
\text { changes }\end{array}$ \\
\hline 7 & 5 & 5 & $\begin{array}{l}\text { MCG } \\
\text { ( peri- } \\
\text { sinus } \\
\text { collection) }\end{array}$ & $\begin{array}{l}\text { MCG } \\
\text { ( peri- } \\
\text { sinus } \\
\text { collection) }\end{array}$ & CT & $\mathrm{CT}$ & Fever & Fever & $\begin{array}{l}\text { Post- } \\
\text { surgi- } \\
\text { cal } \\
\text { changes }\end{array}$ & $\begin{array}{l}\text { Post- } \\
\text { surgi- } \\
\text { cal } \\
\text { changes }\end{array}$ \\
\hline $\begin{array}{l}\text { Patients } \\
\text { with } \\
\text { sec- } \\
\text { ond } \\
\text { surgery }\end{array}$ & $\begin{array}{l}\text { Patients } \\
\text { with } \\
\text { sec- } \\
\text { ond } \\
\text { surgery }\end{array}$ & $\begin{array}{l}\text { Patients } \\
\text { with } \\
\text { sec- } \\
\text { ond } \\
\text { surgery }\end{array}$ & $\begin{array}{l}\text { Patients } \\
\text { with } \\
\text { sec- } \\
\text { ond } \\
\text { surgery }\end{array}$ & $\begin{array}{l}\text { Patients } \\
\text { with } \\
\text { sec- } \\
\text { ond } \\
\text { surgery }\end{array}$ & $\begin{array}{l}\text { Patients } \\
\text { with } \\
\text { sec- } \\
\text { ond } \\
\text { surgery }\end{array}$ & $\begin{array}{l}\text { Patients } \\
\text { with } \\
\text { sec- } \\
\text { ond } \\
\text { surgery }\end{array}$ & $\begin{array}{l}\text { Patients } \\
\text { with } \\
\text { sec- } \\
\text { ond } \\
\text { surgery }\end{array}$ & $\begin{array}{l}\text { Patients } \\
\text { with } \\
\text { sec- } \\
\text { ond } \\
\text { surgery }\end{array}$ & $\begin{array}{l}\text { Patients } \\
\text { with } \\
\text { sec- } \\
\text { ond } \\
\text { surgery }\end{array}$ & $\begin{array}{l}\text { Patients } \\
\text { with } \\
\text { sec- } \\
\text { ond } \\
\text { surgery }\end{array}$ \\
\hline
\end{tabular}




\begin{tabular}{|c|c|c|c|c|c|c|c|c|c|c|}
\hline & $\begin{array}{l}\text { Time } \\
\text { span } \\
\text { from } \\
\text { first } \\
\text { surgery } \\
\text { (days) }\end{array}$ & Indication & Indication & $\begin{array}{l}\text { Second } \\
\text { imaging }\end{array}$ & $\begin{array}{l}\text { Second } \\
\text { imaging }\end{array}$ & $\begin{array}{l}\text { Second } \\
\text { imag- } \\
\text { ing } \\
\text { findings }\end{array}$ & $\begin{array}{l}\text { Second } \\
\text { imag- } \\
\text { ing } \\
\text { findings }\end{array}$ & $\begin{array}{l}\text { Type } \\
\text { of } \\
\text { surgery }\end{array}$ & $\begin{array}{l}\text { Type } \\
\text { of } \\
\text { surgery }\end{array}$ & $\begin{array}{l}\text { Findings } \\
\text { at } \\
\text { surgery }\end{array}$ \\
\hline 1 & 8 & $\begin{array}{l}\text { Fever } \\
+ \\
\text { MRI } \\
\text { find- } \\
\text { ings - } \\
\text { abscess }\end{array}$ & $\begin{array}{l}\text { Fever } \\
+ \\
\text { MRI } \\
\text { find- } \\
\text { ings - } \\
\text { abscess }\end{array}$ & $\begin{array}{l}\text { Yes- } \\
\text { MRI }\end{array}$ & $\begin{array}{l}\text { Yes- } \\
\text { MRI }\end{array}$ & $\begin{array}{l}\text { Post- } \\
\text { surgi- } \\
\text { cal } \\
\text { changes. } \\
\text { Throm- } \\
\text { bosis } \\
\text { with } \\
\text { no } \\
\text { changes }\end{array}$ & $\begin{array}{l}\text { Post- } \\
\text { surgi- } \\
\text { cal } \\
\text { changes. } \\
\text { Throm- } \\
\text { bosis } \\
\text { with } \\
\text { no } \\
\text { changes }\end{array}$ & $\begin{array}{l}\text { peri- } \\
\text { sinus } \\
\text { explo- } \\
\text { ration } \\
\text { and } \\
\text { debrideme }\end{array}$ & $\begin{array}{l}\text { peri- } \\
\text { sinus } \\
\text { explo- } \\
\text { ration } \\
\text { and } \\
\text { ndebridemen }\end{array}$ & $\begin{array}{l}\text { I\&D } \\
\text { of } \\
\text { seroma. } \\
\text { Granulatio } \\
\text { tissue } \\
\text { nt }\end{array}$ \\
\hline 2 & 10 & $\begin{array}{l}\text { Examinatio } \\
\text { under } \\
\text { anastesia }\end{array}$ & $\begin{array}{l}\text { ofxaminatio } \\
\text { under } \\
\text { anastesia }\end{array}$ & & No & - & - & $\begin{array}{l}\text { Examinati } \\
\text { under } \\
\text { anesthesia }\end{array}$ & $\begin{array}{l}\text { ohxaminatio } \\
\text { under } \\
\text { anesthesia }\end{array}$ & $\begin{array}{l}\text { oNlo } \\
\text { findings }\end{array}$ \\
\hline 3 & 4 & $\begin{array}{l}\text { Prolonged } \\
\text { fever }\end{array}$ & $\begin{array}{l}\text { Prolonged } \\
\text { fever }\end{array}$ & $\begin{array}{l}\text { Yes- } \\
\text { MRI }\end{array}$ & $\begin{array}{l}\text { Yes- } \\
\text { MRI }\end{array}$ & SST & $\mathrm{SST}$ & $\begin{array}{l}\text { Revision } \\
\text { mastoidect }\end{array}$ & $\begin{array}{l}\text { Revision } \\
\text { ambstoidect }\end{array}$ & $\begin{array}{l}\text { Evacuation } \\
\text { offiblood } \\
\text { clot over } \\
\text { the } \\
\text { sigmoid } \\
\text { sinus }\end{array}$ \\
\hline 4 & 4 & $\begin{array}{l}\text { Early } \\
\text { VT } \\
\text { extraction }\end{array}$ & $\begin{array}{l}\text { Early } \\
\text { VT } \\
\text { extraction }\end{array}$ & No & No & - & - & $\begin{array}{l}\text { Myringoto } \\
\text { with } \\
\text { VT } \\
\text { insertion }\end{array}$ & $\begin{array}{l}\text { nykyringoton } \\
\text { with } \\
\text { VT } \\
\text { insertion }\end{array}$ & $\begin{array}{l}\text { nfrjarly } \\
\text { VT } \\
\text { extraction }\end{array}$ \\
\hline 5 & 1 & $\begin{array}{l}\text { Early } \\
\text { VT } \\
\text { extraction }\end{array}$ & $\begin{array}{l}\text { Early } \\
\text { VT } \\
\text { extraction }\end{array}$ & No & No & - & - & $\begin{array}{l}\text { Myringoto } \\
\text { with } \\
\text { VT } \\
\text { insertion }\end{array}$ & $\begin{array}{l}\text { ndyryringoton } \\
\text { with } \\
\text { VT } \\
\text { insertion }\end{array}$ & $\begin{array}{l}\text { nfyarly } \\
\text { VT } \\
\text { extraction }\end{array}$ \\
\hline
\end{tabular}

SCG- single complication group, MCG- multiple complications group, SPA- sub-periosteal abscess, SSTsigmoid sinus vein thrombosis, CT - computerized tomography, MRI- magnetic resonance imaging, VTventilation tube, I\&D- incision \& drainage. 
Figure 1. Fever behavior patterns in complicated acute mastoiditis; comparison between SCG and MCG

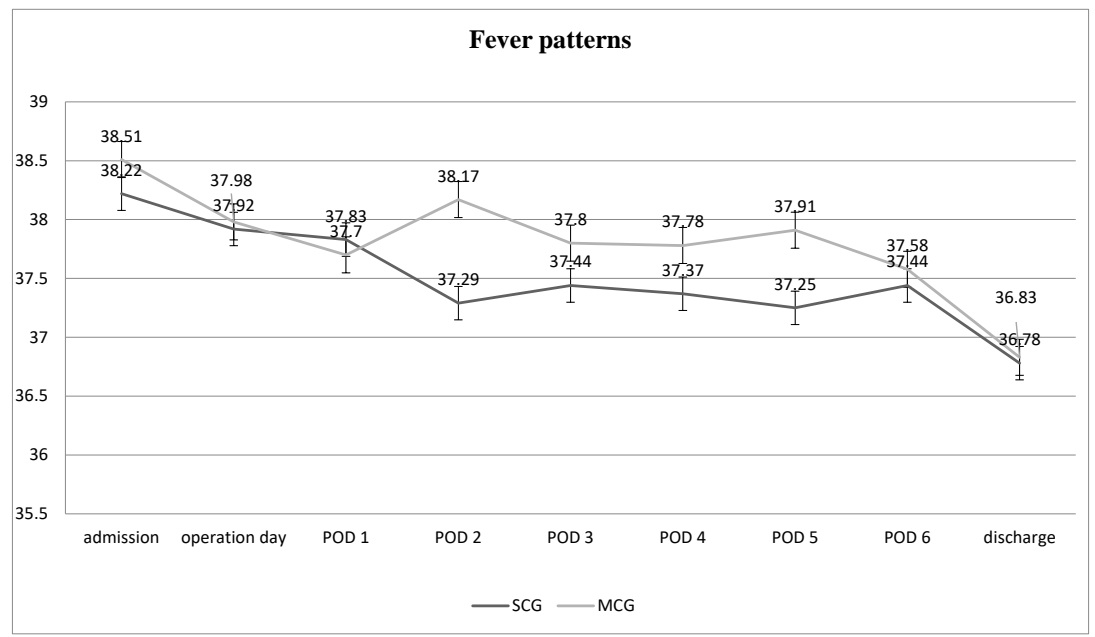

POD - post operative day, SCG - single complication group, MCG - multiple complications group

$\dagger$ - statistically significant $(\mathrm{P}=0.035)$ 
Figure 2. Post-operative fever $\geq 38^{0} \mathrm{C}$; comparison between SCG and MCG patients

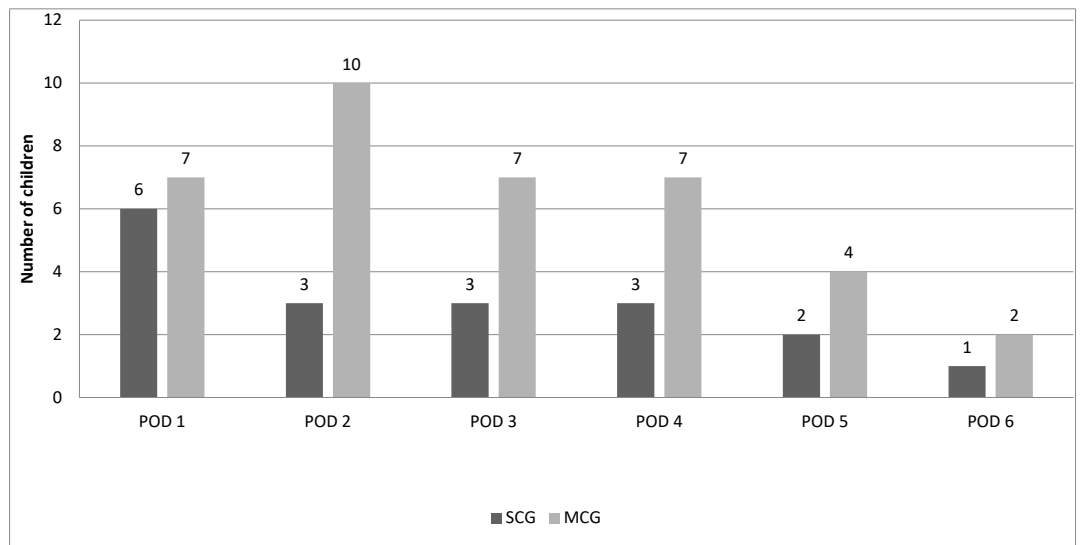

\begin{tabular}{|c|c|c|c|c|c|c|}
\hline POD & 1 & 2 & 3 & 4 & 5 & 6 \\
\hline SCG & $6 / 13$ & $3 / 13$ & $3 / 10$ & $3 / 10$ & $2 / 6$ & $1 / 3$ \\
\hline MCG & $7 / 13$ & $10 / 13$ & $7 / 10$ & $7 / 10$ & $4 / 6$ & $2 / 3$ \\
\hline P-value & 0.728 & 0.013 & 0.141 & 0.141 & 0.398 & 0.601 \\
\hline
\end{tabular}

